IZA DP No. 6128

Immigrant Participation in Welfare Benefits in the Netherlands

Aslan Zorlu

November 2011 


\title{
Immigrant Participation in Welfare Benefits in the Netherlands
}

\author{
Aslan Zorlu \\ University of Amsterdam \\ and IZA
}

\section{Discussion Paper No. 6128 \\ November 2011}

\author{
IZA \\ P.O. Box 7240 \\ 53072 Bonn \\ Germany \\ Phone: +49-228-3894-0 \\ Fax: +49-228-3894-180 \\ E-mail: iza@iza.org
}

\begin{abstract}
Any opinions expressed here are those of the author(s) and not those of IZA. Research published in this series may include views on policy, but the institute itself takes no institutional policy positions.

The Institute for the Study of Labor (IZA) in Bonn is a local and virtual international research center and a place of communication between science, politics and business. IZA is an independent nonprofit organization supported by Deutsche Post Foundation. The center is associated with the University of Bonn and offers a stimulating research environment through its international network, workshops and conferences, data service, project support, research visits and doctoral program. IZA engages in (i) original and internationally competitive research in all fields of labor economics, (ii) development of policy concepts, and (iii) dissemination of research results and concepts to the interested public.
\end{abstract}

IZA Discussion Papers often represent preliminary work and are circulated to encourage discussion. Citation of such a paper should account for its provisional character. A revised version may be available directly from the author. 
IZA Discussion Paper No. 6128

November 2011

\section{ABSTRACT}

\section{Immigrant Participation in Welfare Benefits in the Netherlands ${ }^{*}$}

The efficiency of Dutch welfare system is at the heart of debate as long as immigrants are overrepresented in social welfare benefits during the working age period. This paper examines the degree of participation in social assistance, disability and unemployment benefits across ethnic groups using register data of the entire population in the Netherlands. The analysis shows that migrants are drastically more likely to have a benefit, in particular social assistance and disability benefits. A large part of migrants' dependence can be explained by their background characteristics and immigration history but still a significant unexplained residual is left. Most notably, the probability of welfare use of non-western second generation is about twice as high as the probability of western immigrants, which is a true challenge for policy makers.

JEL Classification: J15, J32

Keywords: $\quad$ ethnic minorities, benefits, inactivity

Corresponding author:

Aslan Zorlu

University of Amsterdam

Faculty of Social and Behavioural Sciences

Nieuwe Prinsengracht 130

1018 VZ Amsterdam

The Netherlands

E-mail: A.Zorlu@uva.nl

\footnotetext{
* I am grateful to Joop Hartog and Martin Kahanec for their insightful comments. Marieke Beentjes provided excellent research assistance. This research was supported by Stichting Instituut Gak.
} 


\section{Introduction}

Numerous studies have shown that assimilation of immigrants in host country labour markets is not a smooth process. As host countries have to cope with difficulties in absorbing immigrants, the debate on the costs of immigration has become increasingly more prominent. The intensity of immigrant welfare use has started to receive much attention from scholars and policy makers. The focus of the debate has been on low degree of labour market participation and correspondingly a high intensity of immigrant welfare use. The low performance of immigrants and their descendants has been increasingly linked to the generous Dutch welfare system. A relatively high concentration of migrants in welfare programs put the affectivity of immigration and integration policies under pressure and challenges national solidarity to ensure the sustainability of welfare system in current setting.

This paper examines the degree of migrants' participation in three major benefits in the Netherlands: social assistance, disability benefits and unemployment benefits, called all together social welfare benefits. These benefits cover a overwhelmingly large part of welfare provisions that are transferred during the working age period. Social assistance is a meanstested programme on the household level, and supports those who have no other opportunity to acquire income to meet basic needs. The Disability benefit is an individual arrangement for those who are not able to work due to health problems often related to the nature of (the last) job. Also the unemployment benefit is an individual temporary arrangement meant to maintain a significant part of wage income after loosing job for a certain period of time. The duration of unemployment benefit depends on the length of employment spell and is limited to two years. Technically, conditions for each sort of benefit are well defined to support those who need these benefits. However, implementation of formal procedure is often sensitive to improper use of these benefits. Both institutions and people sometimes make use of benefits while there is little reason to do so. For example, low skilled workers were massively pushed into disability benefits in the eighties when the restructuring process of Dutch economy was accelerating after the second oil crisis. Particularly 'guest' workers, mostly low skilled manual workers were heavily hit by this process. This regulation was obviously favourable for all parties, employers, government and workers themselves, at least for a time period.

An analysis of the three types of benefits shed light on sources of overrepresentation of migrants in welfare system. We address the question to what extend immigrant groups are particularly sensitive to facilities of the generous Dutch welfare state. We use individual register data from Statistics Netherlands to examine the likelihood of welfare use across ethnic groups.

The structure of the paper is as follows. Next section describes relevant institutional framework for benefit use of migrants. Section 3 briefly reviews findings of previous studies and discusses recent trends in benefit use of successive immigration cohorts. Section 4 introduces data and presents descriptive statistics. Section 5 presents the result of regression analysis. Section 6 concludes.

\section{Institutional Framework}

The welfare system in the Netherlands is often described as being quite universal in its character, is known as one of the most generous welfare states in the world, which provides a high degree of income security for its citizens. The entitlement for most benefits depends on the individual's position in the labour market. To obtain unemployment and disability benefits, a previous spell of paid employment is required. Only those, who work, contribute compulsorily to the unemployment and disability insurance fund and are eligible to concurrent benefits. Individuals who do not qualify for these benefits are generally assigned to means-tested social assistance for the household. This safety net of social assistance is available to legal residents in the Netherlands who have little or no income from work or 
other sources and posses no assets such as a house. Social assistance benefits are paid at subsistence level related to minimum wage. It is obvious that social assistance is benefit for those who have least labour market attachment.

Since a previous period of paid employment is required to obtain unemployment and disability benefits, youth and recently arrived immigrants will not have access or limited access to these benefits. Currently, an individual is entitled to a minimum of three months unemployment benefit if this individual has worked at least 26 out of 36 weeks before unemployment. The maximum duration of unemployment benefit is 35 months which applies to individuals with a working history of 38 years. Since the 1970s the Dutch welfare state has been under great financial pressure. Accordingly, generosity and eligibility conditions have become stricter. Up to 1986 the minimum week requirement was 26 weeks of employment in the last 12 months. If the requirement was not met or the 126 days unemployment benefit was exhausted, this unemployed person was entitled to a follow-up benefit for two years with the prerequisite of having worked for at least six weeks. After the exhaustion of the two benefits, unemployed were entitled to a permanent benefit above social assistance level.

After 1986 the week requirement was lifted to 26 out of 39 weeks for a benefit of six months and a year requirement of 4 out of 5 years was implemented for a possible extension up to five years depending on work history. Current week and year requirements stem from a set of reforms in 2006. The same week requirement and maximum duration regulations are applied to the new 2006 disability act.

Partially disabled who meet the week requirement are temporarily entitled to wage related benefits. As with unemployment benefits duration depends on working history. Individuals who do not meet the week requirement or whose wage related benefits are exhausted are entitled to benefits related to minimum wage or a supplement to current earnings. For fully disabled the week requirement has no benefit level implications. Up to 2006 there was no week requirement and in the 1970s and 1980s eligibility conditions for fully disability benefits were not very restrictive. Institutional design allowed unemployed who were not entitled to or exhausted their unemployment benefits to be declared fully disabled and to be referred to disability benefits. Since 2004 regulations to identify the level of disability are more restrictive and the required period between the first day of sickness and disability benefit eligibility is increased from one year to two years.

In contrast with the unemployment and disability schemes eligibility for social assistance is not dependent on specific work history requirements. The one requirement for the means-tested social assistance benefit is regulated by the in 1998 introduced Linkage Law which allowed to link government registers to detect legal and relevant income position of individuals. The Linkage act decided that for immigrants a regular residence permit for an indefinite period of time is required to receive social assistance. Application for social assistance with a temporary permit could affect the right to residence; the residence permit could be withdrawn and benefits cancelled. However, the Linkage act seemed to have failed, mainly because its contents are incompatible with international treaties (IWI, 2008, pg 24). The Free movement of People and Article 8 of the European Convention on Human Rights make it practically impossible to withdraw a residence permit.

A second limitation to social assistance entitlement was introduced in 2006. With the 2004 EU enlargement, the number of countries in the Schengen area increased by ten. Since the Schengen Convention decides that people can travel and stay freely for three months within the area, i.e. are legitimate residents for three months with social assistance entitlements, government decided the same year that people are not entitled to social assistance for the first three months of their stay in the Netherlands. Furthermore a new social assistance act was designed to reduce the social assistance recipients by integrating claimants into work. 
In addition to the week requirement, year requirement, Linkage act, and three month rule, the participation of immigrants in welfare system is implicitly limited by the Integration Law introduced in 2006. New immigrants from non-EU countries must pass a language test in their home country before entering the Netherlands. Earlier non-EU immigrants, who are dependent on social assistance, must pass two citizenship (integration)-tests in order to be entitled to the permanent settlement in the Netherlands. Extension of a residence permit can only be granted if the immigrant passes the second test, the integration exam, within three and a half years after entering the country. Additionally it was already in 2004 decided that the minimum age of those immigrating on grounds of family formation is lifted from 18 to 21 . The income prerequisite of the 'importing' partner is also increased from $100 \%$ of to $120 \%$ of minimum wage.

\section{Previous Studies}

Research on welfare use of immigrants is not as widespread in the Netherlands as it is in the traditional immigration countries like Australia, United States and Canada. The observed high intensity of the welfare use of immigrants puts the solidarity among Dutch citizens under pressure. Together with the debate on ageing and the fiscal sustainability of the Dutch welfare state, welfare use of immigrants has gained more attention from policy makers and researchers. This has resulted in a number of policy reports prepared by government policy institutions. However, a scholarly study has not been conducted until now. In policy reports, welfare use of immigrants has usually been a small part of broad regular assessments on social cultural integration of immigrants in the Netherlands, so-called integration reports that have been annually prepared.

The integration reports display substantial differences of welfare use between Dutch residents and non-western immigrants. In 2007 one out of five non-western immigrants were claiming either an unemployment benefit, disability benefit or social assistance compared to one out of ten Dutch residents. Social assistance is undoubtedly the most common benefit claimed by non-western immigrant while disability benefits are ranking second in prevalence. For Dutch residents an opposite rank order holds. Among Turkish immigrants disability benefit is most prevalent (almost 10 percent) and even exceeds the percentage of social assistance claims. For Turkish women these percentages are even higher. Snel (2002) ascribes these great percentages to their low level of educational attainment and lack of proficiency in Dutch resulting in jobs with unfavourable labour conditions. Snel also argues that disability benefits are a solution to the cultural conflict whether women should work or not. When women enter permanent disability benefit programs there is no need to discuss their participation in the labour market. Additionally, he mentions the attractiveness of the Dutch disability benefit; the benefit is relatively high and continuation of the benefit does not depend on the duration of the previous period of employment. In theory working four out of five weeks prior to disability satisfies to obtain lifetime entitlement to disability benefits. Apart from the Turks all other non-western immigrants depend predominantly on social assistance. Surinam Immigrants are performing best and Antillean/Aruban and Moroccan immigrants worst in terms of social assistance. Surinam women are even outperforming Dutch gender counterparts in financial independency. For Antillean and Moroccans the large number of lone parents should be taken into account when analysing social assistance figures (integration report 2009).

Different than major migrant groups, refugee migrants, who are mainly from Somali, Afghanistan, Iraq and Iran, are highly dependent on social assistance benefits. This has to do with legal procedure through which refugees should pass in the Netherlands. After gaining 
residence permit, refugees usually start with social assistance. Often simultaneously they are attending training programmes to learn the Dutch language and institutions and to prepare for Dutch labour market (Hartog and Zorlu 2009; Klaver et al., 2007).

In the 2008 Integration Report, non-western immigrants are distinguished into generations. It is reported that the intensity of welfare use is particularly high for first generation immigrants, 23 percent. Social assistance use of second-generation immigrants is slightly above the percentage of Dutch residents, around 7 percent. The second generation even claims unemployment and disability benefits less frequently than Dutch residents. The strong age difference between the first and second generation explains a large part of differences in benefit use. However, after controlling for age, the first generation has still a higher level of welfare dependency (Van der Vliet et al. 2007; Ferber 2008). Furthermore, integration reports indicate that the welfare use of all non-western immigrants has been found to be more sensitive to business-cycles compared with the welfare use of Dutch residents.

While the overall social assistance use of non-western immigrants is more frequent than that for Dutch, the observed exit to regular jobs seems greater for non-western immigrants. However, this is caused by the young age structure of non-western immigrants. After controlling for age, non-western immigrants appear to have an unfavourable position (Kroeze 2008). Roodenburg (2001) perform a cost-benefit analysis of immigration and concludes that net contribution of non-western immigrants to the public sector is negative allowing different characteristics of immigrant groups. However when non-western immigrants are at the age of 25 upon their arrival in the Netherlands, their net contribution to the public sector tend to be positive. Different than largest traditional immigrant groups, more recent immigrants from Central East European (CEE) countries have a net positive contribution (SEO, 2008). These immigrants are lees likely unemployed and they participate less frequently in unemployment and social assistance benefits. Their position is pretty comparable with native Dutch (Versantvoort et al. 2006).

\section{Welfare Use of Recent Immigrants: Trend}

The participation of immigrants in the labour market seems to go hand in hand with the participation of immigrants in welfare use. Both employment and welfare use increases with the duration of their stay in the Netherlands. Figure 1 shows employment rate and welfare dependency rate of successive immigration cohorts upon arrival and development in their position with time elapses. Such a correlation is not a coincidence. Eligibility to unemployment and disability benefits requires a previous period of paid employment. At the same time it indicates that immigrants face difficulties to leave welfare system in favour of a job.

First, we provide a general picture of welfare dependency of successive immigration cohorts in the period of 1999-2006, focusing all kinds of benefits for the working age population. Figure 1 shows changes in the welfare use of successive immigration cohorts as the duration of stay in the Netherlands increases. The general pattern is that about five to seven percent of immigrants claims welfare benefits in the year arrival. This percentage increases in the following six years for the immigration cohorts 1999 and 2000. However, the share of immigrants arrived since 2001 in welfare benefits goes up less strong with duration of stay. Particularly, the 2002 and 2003 cohorts show a substantially smaller increase in welfare use compared to previous cohorts. The weaker rise of welfare use of the successive immigration cohorts would be explained by stricter eligibility conditions of social assistance and disability benefit, and possibly economic recovery after 2004.

Figure 1. Welfare use of non-western immigrants by immigration cohort 


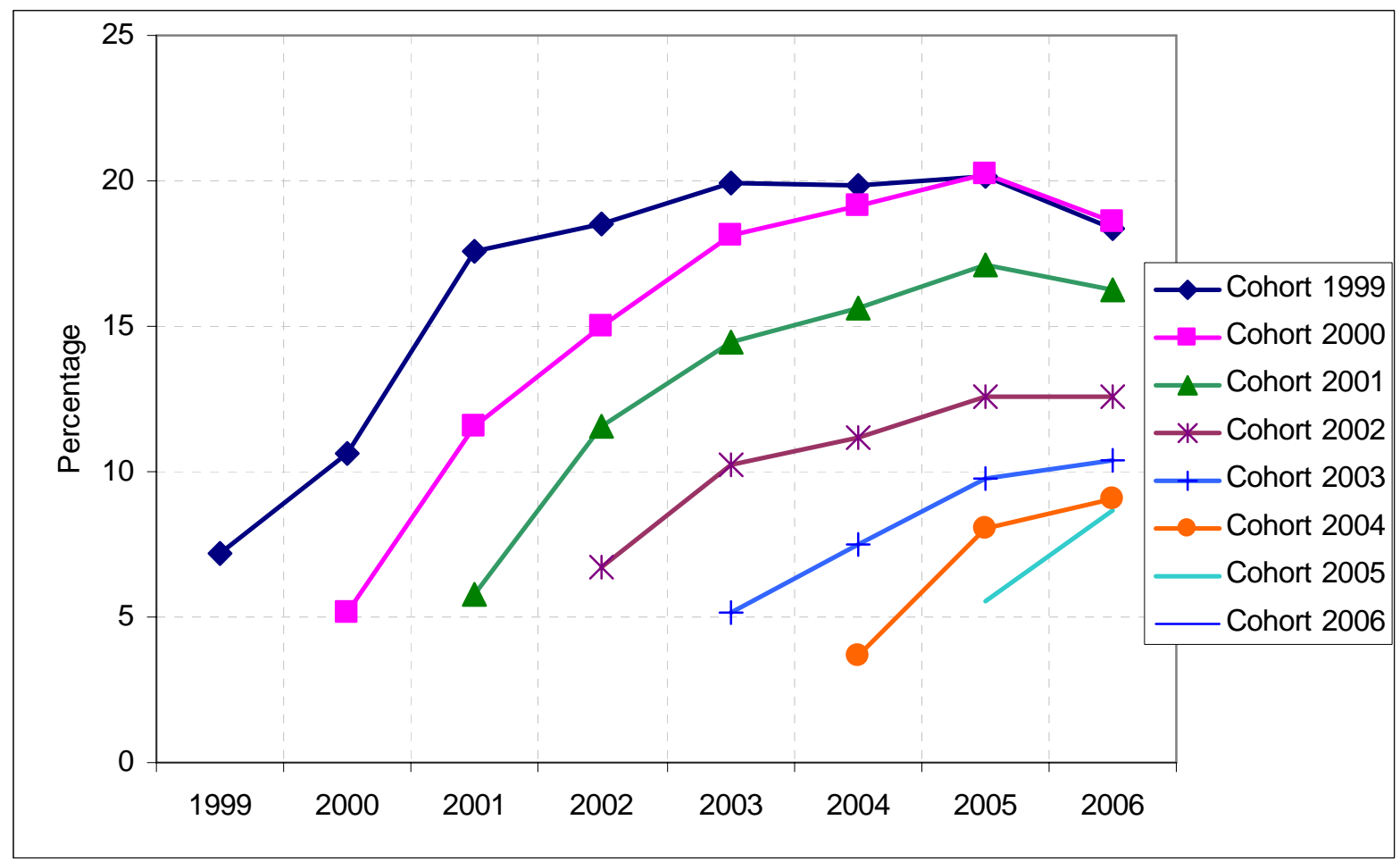

Employment non-western im migrants (\%)

Welfare use of non-western im migrants (\%)
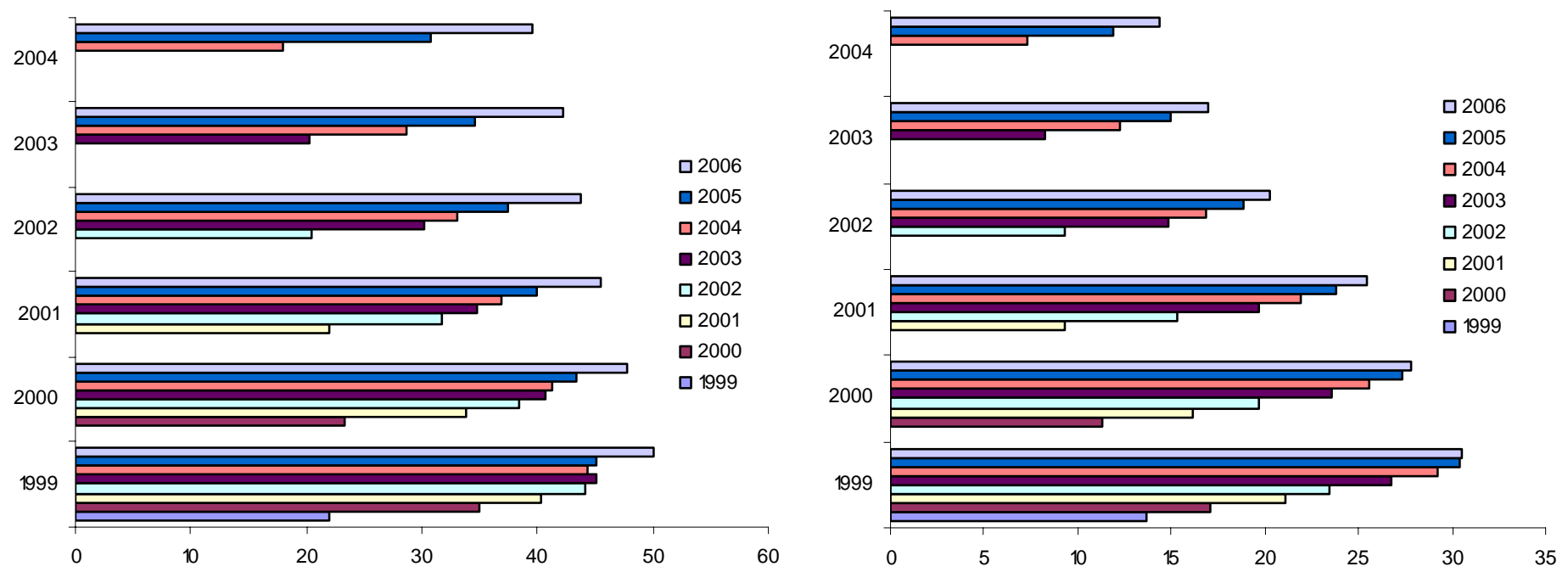

When comparing different cohorts, the percentage of newly arrived immigrants claiming welfare is decreasing over the years. This outcome is remarkable since the employment rate of newly arrived immigrants is also decreasing. Upon their arrival immigrants are mainly entitled to social assistance, access to unemployment and disability benefit is limited in the first years of their stay. A rise in employment does not necessarily imply an increase of benefit entitlements, and a subsequent rise in welfare use. Therefore, as employment of newly arrived immigrants decreases, a greater dependency on welfare use may be expected. Particularly, the 2004 cohort shows substantially smaller percentages of both employment and 
welfare use compared to previous cohorts. The decrease in employment can be explained by the economic downturn after 2001. The decline in welfare use of the successive cohorts can be attributed to stricter eligibility conditions. In particular the 2004 cohort experienced various restrictions on eligibility conditions of disability benefit and social assistance.

Since access to social assistance and disability benefit is not related to (the extent of) the previous employment period and overall welfare use of non-western immigrants mainly involves social assistance and disability benefit, the decline of welfare use of the successive immigration cohorts would be explained by stricter regulation and eligibility conditions, rather than improved economic climate. Between 1999 and 2003 the percentage of nonwestern immigrants receiving disability benefits has been rather steady, so as to fall after 2004 . Social assistance use shows a similar development.

\section{Data and Descriptive Statistics}

We use register data for 2005 from Statistics Netherlands, the Social Statistical Database (SSB). The SSB is a set of information registered by local and national governments and other public institutions such as tax offices, institutions of the welfare system and municipalities. This database includes basic personal characteristics such as age, gender, ethnicity, data of immigration and nationality as well as relevant labour market characteristics of individuals, like whether an individual has disability and unemployment benefit, social assistance or a job. The SSB covers the entire population of the Netherlands. Since an overwhelmingly large part of personal transactions and relations with public and private institutions base on registers, this database represents a solid formal picture of the Dutch society. It is obvious that illegal immigrants are not included in this database. Besides, illegal immigrants are by definition formally excluded from all benefits and social assistance programs. We select all people aged between 19 to 64 years.

The advantage of register data is that we are able to distinguish sub-groups within immigrant groups without losing statistical power. Table 1 presents the percentages of first and second generation immigrants and native Dutch who receive social assistance, disability and unemployment benefits broken down by gender. It is immediately obvious that women are more likely to obtain social assistance compared to men and all non-western immigrant groups are highly dependent on social assistance. The second generation of non-western immigrants is considerably less dependent on social assistance, compared to their parents. The percentage of first generation immigrants from non-western countries receiving social assistance is drastically high, particularly for Moroccan, other non-western and Antillean immigrants. They are followed by Surinamese and Turkish immigrants. The percentage of western immigrants with social assistance is closer to that of native Dutch. Different from social assistance use, the percentage of men receiving disability benefits is higher than that of women. Claiming disability benefits is more common for the native Dutch population: 8.64\% of Dutch men and $7.2 \%$ of Dutch women have a disability benefit. Only first generation Turkish Moroccan, and Surinamese men and Turkish and Surinamese women appear to have larger disability benefit percentages compared to their Dutch gender counterparts. Other ethnic minority groups and immigrants of the second generation are underrepresented in disability benefit use. Ethnic minority groups are often underrepresented in unemployment benefit. Especially the second generation is less likely to claim unemployment benefits. This outcome is possibly related to the nature of unemployment benefit, continuation of unemployment benefit is conditional to employment history. It is worth noticing that the relatively small share of second generation in social assistance and disability benefits is probably caused by the young age structure of this group. In the next section, we take age differences into account to obtain a more standardised comparison. 
In practice, it is likely that a person can have more than one type of benefit since the benefits of interest are designed to satisfy different needs. To see person specific benefit dependency, we also look at total welfare use which covers the recipients of social assistance, disability and unemployment benefits. About 12 percent of Dutch people receive welfare benefits as opposed to about 30 percent of Turkish and Moroccan immigrants (first generations). This percentage is between 21 and 27 for Surinamese, Antillean and other nonwestern immigrants. Only 13 percent of western immigrants have a welfare benefit, which is lower than that for Dutch.

Table 1. Social welfare use by gender and immigrant generation in 2005, percentages

\begin{tabular}{|c|c|c|c|c|c|c|c|c|}
\hline & \multicolumn{2}{|c|}{ Social Assistance } & \multicolumn{2}{|c|}{ Disability } & \multicolumn{2}{|c|}{ Unemployment } & \multicolumn{2}{|c|}{ Total } \\
\hline & Male & Female & Male & Female & Male & Female & Male & Female \\
\hline Moroccan- 1st gen & 16.01 & 22.32 & 13.73 & 6.81 & 4.93 & 2.19 & 33.01 & 30.53 \\
\hline Moroccan- 2nd gen & 7.40 & 6.86 & 3.40 & 3.55 & 1.52 & 1.68 & 12.13 & 11.79 \\
\hline Turkish- 1st gen & 10.07 & 16.53 & 14.76 & 14.61 & 5.01 & 3.80 & 28.45 & 33.93 \\
\hline nd gen & 5.20 & 6.55 & 3.77 & 4.71 & 2.11 & 2.52 & 10.89 & 13.39 \\
\hline Surinamese- 1st gen & 9.07 & 13.47 & 9.38 & 10.28 & 4.17 & 3.77 & 21.97 & 26.54 \\
\hline Surinamese- 2nd gen & 5.68 & 8.37 & 3.65 & 4.15 & 1.68 & 1.84 & 10.89 & 14.03 \\
\hline Antillean- 1st gen & 13.41 & 21.58 & 4.47 & 4.61 & 3.49 & 3.46 & 21.07 & 29.03 \\
\hline Antillean- 2nd gen & 3.95 & 5.60 & 3.36 & 3.88 & 1.62 & 1.74 & 8.81 & 11.02 \\
\hline Other non-west- 1st gen & 14.81 & 19.04 & 3.26 & 2.23 & 3.16 & 2.07 & 20.77 & 23.02 \\
\hline Other non-west- 2nd gen & 2.79 & 3.99 & 3.25 & 3.30 & 1.16 & 1.19 & 7.07 & 8.27 \\
\hline Western- 1st gen & 3.96 & 5.64 & 6.70 & 5.72 & 3.17 & 2.53 & 13.37 & 13.45 \\
\hline Western- 2nd gen & 2.74 & 4.17 & 8.78 & 8.55 & 3.05 & 2.65 & 14.12 & 14.84 \\
\hline Total Imm. & 7.76 & 10.63 & 7.68 & 6.84 & 3.36 & 2.64 & 18.19 & 19.56 \\
\hline Dutch & 1.60 & 2.78 & 8.64 & 7.2 & 2.36 & 2.05 & 12.23 & 12.12 \\
\hline
\end{tabular}

Table 2. shows mean values of variables used to explain welfare dependency by migrant group. The age distribution varies across migrant groups. Non-western migrants are in general relatively young. Most migrants from the main immigrant groups, i.e. Moroccans, Surinamese and Turks entered the Netherlands in the 1970s and 1980s while the group Other non-western immigrants arrived in more recent years. Arrival time of Western migrants is quite equally distributed over years. Unfortunately, the level of education is unknown for the majority of the population (for more than 70 percent), and available educational information is selective which requires a careful interpretation of the impact of education. Nevertheless, the observed educational level of non-western migrants is drastically lower than that of native Dutch and Western migrants. Most Turkish and Moroccan migrants are low educated. Also marital status differs significantly across migrant groups. The majority of Turkish, Moroccan and Western migrants is married while Antillean, Surinamese and other non-western are less frequently married and more likely separated.

Table 2 Mean values of variables by migrant groups

\begin{tabular}{lrrrrrr}
\hline & Moroc & Turk & \multicolumn{5}{c}{ Surinam Antillean OthN-W West } \\
\hline Social Assistance & 0,165 & 0,115 & 0,102 & 0,149 & 0,154 & 0,041 \\
Disability benefit & 0,090 & 0,123 & 0,083 & 0,044 & 0,028 & 0,075 \\
Unemployment benefit & 0,032 & 0,040 & 0,034 & 0,031 & 0,025 & 0,028 \\
Woman & 0,474 & 0,480 & 0,525 & 0,499 & 0,477 & 0,513 \\
2nd gen (mixed) & 0,019 & 0,014 & 0,081 & 0,141 & 0,053 & 0,445 \\
2nd gen & 0,188 & 0,211 & 0,188 & 0,067 & 0,049 & 0,094 \\
age1924 & 0,188 & 0,163 & 0,158 & 0,194 & 0,182 & 0,095 \\
age2529 & 0,169 & 0,161 & 0,116 & 0,162 & 0,147 & 0,103 \\
\hline
\end{tabular}




\begin{tabular}{|c|c|c|c|c|c|c|}
\hline age3034 & 0,161 & 0,161 & 0,119 & 0,134 & 0,144 & 0,113 \\
\hline age3539 & 0,146 & 0,155 & 0,137 & 0,125 & 0,149 & 0,129 \\
\hline age4044 & 0,115 & 0,140 & 0,135 & 0,108 & 0,134 & 0,126 \\
\hline age4549 & 0,079 & 0,083 & 0,122 & 0,098 & 0,104 & 0,114 \\
\hline age5054 & 0,055 & 0,051 & 0,100 & 0,079 & 0,072 & 0,111 \\
\hline Immigrated between 2004-2005 & 0,024 & 0,027 & 0,012 & 0,033 & 0,084 & 0,056 \\
\hline Immigrated between 2000-2003 & 0,078 & 0,075 & 0,034 & 0,158 & 0,223 & 0,084 \\
\hline Immigrated between 1995-1999 & 0,093 & 0,088 & 0,052 & 0,151 & 0,222 & 0,069 \\
\hline Immigrated between 1990-1994 & 0,137 & 0,123 & 0,112 & 0,124 & 0,164 & 0,061 \\
\hline Immigrated between 1980-1989 & 0,282 & 0,228 & 0,170 & 0,209 & 0,134 & 0,058 \\
\hline Immigrated between 1970-1979 & 0,163 & 0,222 & 0,314 & 0,082 & 0,061 & 0,056 \\
\hline Immigrated before 1970 & 0,014 & 0,012 & 0,034 & 0,034 & 0,008 & 0,075 \\
\hline edu_extended primary & 0,071 & 0,057 & 0,063 & 0,080 & 0,062 & 0,032 \\
\hline edu_secondary & 0,105 & 0,093 & 0,146 & 0,168 & 0,113 & 0,109 \\
\hline edu_higher vocational & 0,030 & 0,026 & 0,053 & 0,058 & 0,038 & 0,057 \\
\hline edu_academic & 0,008 & 0,010 & 0,026 & 0,028 & 0,025 & 0,042 \\
\hline edu_missing & 0,725 & 0,752 & 0,696 & 0,642 & 0,691 & 0,745 \\
\hline married & 0,590 & 0,660 & 0,288 & 0,214 & 0,393 & 0,463 \\
\hline Widowed & 0,008 & 0,011 & 0,011 & 0,005 & 0,010 & 0,015 \\
\hline Separated & 0,075 & 0,090 & 0,179 & 0,103 & 0,089 & 0,096 \\
\hline Partner & 0,000 & 0,001 & 0,003 & 0,002 & 0,002 & 0,005 \\
\hline Immigrant_Dutch citizen & 0,004 & 0,010 & 0,900 & 0,970 & 0,250 & 0,240 \\
\hline Immigrant_Dutch and Foreign citizen & 0,620 & 0,590 & 0,050 & 0,001 & 0,300 & 0,190 \\
\hline $\mathrm{N}$ & \multicolumn{2}{|c|}{192161230919} & 230517 & 91251 & \multicolumn{2}{|c|}{3928181011471} \\
\hline
\end{tabular}

\section{Determinants of Welfare Use}

Ethnic differences in welfare use displayed, can be caused by specific observed characteristics and migration history of immigrants. To facilitate more reliable comparisons of welfare use of ethnic groups, we conduct a regression analysis using observed characteristics using data on migrant groups (first and second generation). We estimate the following probit specification of the probability that a person receives social assistance, disability or unemployment benefit

$P_{i}($ Social Welfare $>0)=\alpha X_{i}+\sum_{t} \beta_{t} Y S M_{i t}+\eta M_{i j g}+\phi C_{i}+\varepsilon_{i}$

$X$ is a vector of control variables such as age, gender, marital status and education level. Information about the level of education is only known for a part of the population, about a quarter. Therefore, we use a control variable in the case of unknown educational levels, and we also estimate the same model using only the sample of people with observed levels of education and applying weight to the different levels of education to raise this sample to the true population. YSM is a vector of dummies indicating time intervals of immigration years in the Netherlands (these dummies are set to zero for Dutch and the second generation immigrants), immigration years before 1970 is the reference category. $M$ is a set of dummy variables indicating country of origin groups and second generation within each group. Western first generation immigrants are the reference category because these groups are most comparable with native Dutch. $C$ is a vector of dummy variables indicating whether a migrant (first and second generation) has Dutch or both Dutch and foreign nationality; having only a foreign citizenship is the reference category, $\varepsilon$ is the error term. 
First, we run separate probit models for the population of all migrant groups to assess differences in welfare use. Dutch population is not included in this analysis. In this analysis, first generation western immigrants are used as the reference category relying on the fact that they are most comparable immigrant group with native Dutch. In addition to this analysis of migrant groups, we draw a 10 percent sample from the Dutch population between 19 and 64 years. This facilitates the comparison of inter-ethnic differences holding observed characteristics constant.

Table 3 displays the estimates for each type of benefit and total benefits. Since first generation western immigrants are the reference category, ethnic difference in benefit claims should be measured with respect to this group. The estimates are presented as odds ratios. This means that an odds ratio gives the relative magnitude of effect of a indicator variable with respect to the reference group: an odds ratio of one represents an equal effect of certain indicator variable and the reference category while an odds ratio of larger (smaller) than one suggests a larger (smaller) effect for indicator variable. It is immediately clear that differences in the intensity of claims of social assistance and disability benefits across immigrant groups decline drastically for first generation immigrants compared to the results in Table 1 when we control for the observed characteristics mentioned above. On the other hand, these differences increase for the second generation after controlling for observed variables, particularly for age.

\section{Social Assistance}

The estimates for ethnic differences in social assistance use indicate that the probability of having social assistance is two and half times greater for Antilleans than for western immigrants (the reference category). This probability is about two times higher for other nonwestern and Moroccan immigrants, and about one and half times higher for Turkish and Surinamese immigrants. Also second generation immigrants have a higher probability of claiming social assistance than the reference category. Among the second generation, especially those whose both parents were born abroad have a higher probability compared to the mixed second generation who have one foreign born parent. For almost all migrant groups, the second generation has a higher probability of social assistance than the first generation.

The relation between social assistance use and the duration of stay is not linear. Interestingly, immigrants who arrived between 1995 and 1999 have the highest probability of social assistance while the most recent immigrants have the lowest probability. The probability of social assistance claims is monotonously decreasing for earlier immigration cohorts. The highest prevalence of social assistance for immigration cohort 1995-99 is likely related to the composition of immigrants rather than the pure duration of residence effect. The probability of social assistance use is significantly smaller for most recent immigrants. This could be explained by the 1998 Linkage Act and the 2004 social assistance reforms which imposed more restriction on social assistance entitlement of immigrants.

\section{Disability benefit}

The probability of disability benefit is almost twice as higher for Turkish immigrants and one and half times higher for Moroccan immigrants than for western immigrants. Turkish and Moroccan second generation is also overrepresented in disability benefits after controlling for age and other observed characteristics. The probability of disability benefit goes clearly up with the duration of stay in the Netherland. Earlier immigration cohorts are more likely to be in disability programmes, which is an expected outcome. They are usually unskilled immigrants who lost their job either due to health problems or in the restructuring period of the Dutch economy. Another explanation is that most recent immigrants could not build up employment history to facilitate disability benefits. 


\section{Unemployment benefit}

The probability of unemployment benefit is higher for all first generation non-western groups compared to western immigrants after controlling for the observed characteristics. Also Moroccan, Turkish, Surinamese second generation have a significant higher probability of unemployment benefit while differences for mixed second generation from the same groups are not statistically significant. Strikingly, the probability of unemployment benefit is the lowest for most recent immigrants and this goes up with duration of stay whereas it reaches the top at the 1990-1994 immigration cohort.

\section{Covariates}

The probability of disability benefits or social assistance use seems to increase with age. Older ages are associated with deteriorating health conditions and increasing labour market experience generating higher chances for entitlement for these benefits. On the contrary, unemployment benefits go down with age. This is probably due to greater job security in older ages. Older people are more experienced and have probably been working longer for the same employer. The two youngest age cohorts are however less likely to receive unemployment benefits, possibly due to a short employment history, and greater chances to being still in education. Not surprisingly, the probability of disability benefits or social assistance decreases with education level. Remarkably, the unemployment benefit use is quite similar across educational levels. Separated and unmarried individuals are most likely to have social assistance become welfare dependent while widowed people are significantly less likely to have any benefit. Benefit use is also low for couples.

Immigrants who have Dutch citizenship but do not have a foreign citizenship are more likely to have an unemployment or disability benefit while immigrants who were granted Dutch citizenship and keep their original citizenship have a lower probability of unemployment or disability benefits. These outcomes are possibly related to the composition of these two groups, rather than pure effect of naturalisation. The first group, immigrants with only Dutch citizenship, is likely dominated by refugee migrants who lost their original nationality per definition in asylum procedure. The second groups is mainly composed by immigrants who have taken Dutch citizenship without losing the original citizenship in especially the 1990s, before the new immigration law was affected in 2001, which requires renouncing the original citizenship.

Table 1 Probit estimations of welfare use

\begin{tabular}{|c|c|c|c|c|}
\hline \multirow{2}{*}{ Moroccan- 1st gen } & \multicolumn{2}{|c|}{ Social Assistance Disability } & \multirow{2}{*}{$\begin{array}{l}\text { Unemployment } \\
1.130^{\star \star \star} \\
(0.009)\end{array}$} & \multirow{2}{*}{$\begin{array}{l}\text { All benefits } \\
1.826^{\star \star \star} \\
(0.009)\end{array}$} \\
\hline & $\begin{array}{l}1.865^{\star \star \star} \\
(0.012)\end{array}$ & $\begin{array}{l}1.618^{\star \star \star} \\
(0.010)\end{array}$ & & \\
\hline Moroccan- 2nd gen (mixed) & $\begin{array}{l}1.995^{\star \star \star x} \\
(0.069)\end{array}$ & $\begin{array}{l}1.108^{*} \\
(0.042)\end{array}$ & $\begin{array}{l}0.971 \\
(0.051)\end{array}$ & $\begin{array}{l}1.355^{\star \star \star} \\
(0.038)\end{array}$ \\
\hline Moroccan- 2nd gen & $\begin{array}{l}2.058^{\star \star \star *} \\
(0.029)\end{array}$ & $\begin{array}{l}1.065^{\star \star \star} \\
(0.016)\end{array}$ & $\begin{array}{l}1.086^{\star \star *} \\
(0.021)\end{array}$ & $\begin{array}{l}1.368^{\star \star \star *} \\
(0.015)\end{array}$ \\
\hline Turkish- 1st gen & $\begin{array}{l}1.509 * * * \\
(0.010)\end{array}$ & $\begin{array}{l}1.919 * \star \star \\
(0.011)\end{array}$ & $\begin{array}{l}1.206^{\star * *} \\
(0.009)\end{array}$ & $\begin{array}{l}1.882^{\star \star \star} \\
(0.009)\end{array}$ \\
\hline Turkish- 2nd gen (mixed) & $\begin{array}{l}1.875^{\star \star \star x} \\
(0.069)\end{array}$ & $\begin{array}{l}1.145^{\star \star \star} \\
(0.043)\end{array}$ & $\begin{array}{l}0.942 \\
(0.051)\end{array}$ & $\begin{array}{l}1.325^{\star \star} \\
(0.039)\end{array}$ \\
\hline Turkey-2nd gen & $\begin{array}{l}1.791^{\star \star \star} \\
(0.025)\end{array}$ & $\begin{array}{l}1.173^{\star \star \star} \\
(0.015)\end{array}$ & $\begin{array}{l}1.183^{\star \star \star} \\
(0.019)\end{array}$ & $\begin{array}{l}1.326^{\star \star \star} \\
(0.013)\end{array}$ \\
\hline Surinamese- 1st gen & $\begin{array}{l}1.525^{\star * \star x} \\
(0.009)\end{array}$ & $\begin{array}{l}1.133^{* * *} \\
(0.007)\end{array}$ & $\begin{array}{l}1.063^{\star \star *} \\
(0.008)\end{array}$ & $\begin{array}{l}1.362^{\star \star \star} \\
(0.006)\end{array}$ \\
\hline Surinamese- 2nd gen (mixed) & $\begin{array}{l}1.729 * \star x \\
(0.031)\end{array}$ & $\begin{array}{l}1.065^{\star \star \star} \\
(0.018)\end{array}$ & $\begin{array}{l}0.928 \\
(0.021)\end{array}$ & $\begin{array}{l}1.229 \star \star \star \\
(0.016)\end{array}$ \\
\hline Surinamese- 2nd gen & $\begin{array}{l}2.111^{\star \star \star} \\
(0.027)\end{array}$ & $\begin{array}{l}0.944^{\star \star \star} \\
(0.013)\end{array}$ & $\begin{array}{l}0.990 \star \star \star \\
(0.017)\end{array}$ & $\begin{array}{l}1.332^{\star \star \star} \\
(0.013)\end{array}$ \\
\hline Antillean- 1st gen & $\begin{array}{l}2.151^{\star * * x} \\
(0.015)\end{array}$ & $\begin{array}{l}0.956^{\star \star \star} \\
(0.009)\end{array}$ & $\begin{array}{l}1.117^{\star * \star} \\
(0.011)\end{array}$ & $\begin{array}{l}1.714^{\star \star *} \\
(0.010)\end{array}$ \\
\hline
\end{tabular}




\begin{tabular}{|c|c|c|c|c|}
\hline Antillean- 2nd gen (mixed) & $\begin{array}{l}1.523^{\star \star \star} \\
(0.036)\end{array}$ & $\begin{array}{l}0.983 \\
(0.022)\end{array}$ & $\begin{array}{l}0.889 \star \star \star \\
(0.026)\end{array}$ & $\begin{array}{l}1.094^{\star \star \star} \\
(0.019)\end{array}$ \\
\hline Antillean- 2nd gen & $\begin{array}{l}2.003^{\star \star \star} \\
(0.055)\end{array}$ & $\begin{array}{l}0.921^{\star} \\
(0.031)\end{array}$ & $\begin{array}{l}0.954 \\
(0.041)\end{array}$ & $\begin{array}{l}1.271^{\star \star \star} \\
(0.029)\end{array}$ \\
\hline Other non-west- 1st gen & $\begin{array}{l}1.927^{\star \star *} \\
(0.009)\end{array}$ & $\begin{array}{l}0.925^{\star \star *} \\
(0.006)\end{array}$ & $\begin{array}{l}1.035^{\star \star *} \\
(0.007)\end{array}$ & $\begin{array}{l}1.535^{\star \star *} \\
(0.006)\end{array}$ \\
\hline Other non-west- 2nd gen (mixed) & $\begin{array}{l}1.409^{*} \\
(0.029)\end{array}$ & $\begin{array}{l}0.978 \\
(0.017)\end{array}$ & $\begin{array}{l}0.857^{\star * *} \\
(0.021)\end{array}$ & $\begin{array}{l}1.038^{\star * *} \\
(0.015)\end{array}$ \\
\hline Other non-west- 2nd gen & $\begin{array}{l}1.578^{\star \star \star *} \\
(0.032)\end{array}$ & $\begin{array}{l}0.878^{\star \star \star} \\
(0.019)\end{array}$ & $\begin{array}{l}0.819^{\star * *} \\
(0.024)\end{array}$ & $\begin{array}{l}1.028 \\
(0.016)\end{array}$ \\
\hline Western- 2nd gen (mixed) & $\begin{array}{l}1.204^{\star * *} \\
(0.011)\end{array}$ & $\begin{array}{l}1.008 \\
(0.006)\end{array}$ & $\begin{array}{l}0.896^{\star \star *} \\
(0.007)\end{array}$ & $\begin{array}{l}1.038^{\star * *} \\
(0.0065)\end{array}$ \\
\hline Western- 2nd gen & $\begin{array}{l}1.300^{* * *} \\
(0.015)\end{array}$ & $\begin{array}{l}0.927^{\star \star *} \\
(0.008)\end{array}$ & $\begin{array}{l}0.973^{\star} \\
(0.011)\end{array}$ & $\begin{array}{l}1.036^{* * *} \\
(0.007)\end{array}$ \\
\hline Immigrated between 2004-2005 & $\begin{array}{l}0.712^{\star \star \star} \\
(0.009)\end{array}$ & $\begin{array}{l}0.126^{\star * *} \\
(0.007)\end{array}$ & $\begin{array}{l}0.425^{\star \star \star} \\
(0.009)\end{array}$ & $\begin{array}{l}0.383^{\star * \star} \\
(0.004)\end{array}$ \\
\hline Immigrated between 2000-2003 & $\begin{array}{l}1.161^{\text {*** }} \\
(0.011)\end{array}$ & $\begin{array}{l}0.284^{\star * *} \\
(0.004)\end{array}$ & $\begin{array}{l}0.657^{\star \star *} \\
(0.007)\end{array}$ & $\begin{array}{l}0.640^{\star * *} \\
(0.004)\end{array}$ \\
\hline Immigrated between 1995-1999 & $\begin{array}{l}1.418^{\star * * *} \\
(0.013)\end{array}$ & $\begin{array}{l}0.566^{\star * *} \\
(0.005)\end{array}$ & $\begin{array}{l}0.950 \text { *** } \\
(0.009)\end{array}$ & $\begin{array}{l}0.873^{\star * *} \\
(0.005)\end{array}$ \\
\hline Immigrated between 1990-1994 & $\begin{array}{l}1.378^{\star \star * *} \\
(0.012)\end{array}$ & $\begin{array}{l}0.778^{\star \star * *} \\
(0.006)\end{array}$ & $\begin{array}{l}1.039 * * * \\
(0.010)\end{array}$ & $\begin{array}{l}0.955 \\
(0.006)\end{array}$ \\
\hline Immigrated between 1980-1989 & $\begin{array}{l}1.285^{\star \star \star} \\
(0.011)\end{array}$ & $\begin{array}{l}0.851^{\star \star \star} \\
(0.006)\end{array}$ & $\begin{array}{l}0.969 * * * \\
(0.009)\end{array}$ & $\begin{array}{l}0.941^{\star \star *} \\
(0.005)\end{array}$ \\
\hline Immigrated between 1970-1979 & $\begin{array}{l}1.212^{\star \star \star} \\
(0.011)\end{array}$ & $\begin{array}{l}1.030^{\star \star \star *} \\
(0.007)\end{array}$ & $\begin{array}{l}0.933^{\star \star \star} \\
(0.008)\end{array}$ & $\begin{array}{l}1.050^{\star \star \star *} \\
(0.006)\end{array}$ \\
\hline Immigrant_Dutch citizen & $\begin{array}{l}0.063^{\star \star *} \\
(0.001)\end{array}$ & $\begin{array}{l}1.659^{\star \star *} \\
(0.026)\end{array}$ & $\begin{array}{l}1.586^{\star \star *} \\
(0.033)\end{array}$ & $\begin{array}{l}0.113^{\star \star \star *} \\
(0.001)\end{array}$ \\
\hline Immigrant_Dutch and Foreign citizen & $\begin{array}{l}0.913^{\star \star \star} \\
(0.012)\end{array}$ & $\begin{array}{l}0.775^{\star \star \star} \\
(0.017)\end{array}$ & $\begin{array}{l}0.811^{\star \star *} \\
(0.024)\end{array}$ & $\begin{array}{l}0.845^{\star \star \star} \\
(0.011)\end{array}$ \\
\hline Age1924 & $\begin{array}{l}0.463^{\star * *} \\
(0.003)\end{array}$ & $\begin{array}{l}0.345^{\star * *} \\
(0.003)\end{array}$ & $\begin{array}{l}0.472^{\star * *} \\
(0.005)\end{array}$ & $\begin{array}{l}0.312^{* * *} \\
(0.002)\end{array}$ \\
\hline Age2529 & $\begin{array}{l}0.655^{\star \star \star} \\
(0.004)\end{array}$ & $\begin{array}{l}0.370^{\star \star \star} \\
(0.003)\end{array}$ & $\begin{array}{l}0.733^{\star \star \star} \\
(0.006)\end{array}$ & $\begin{array}{l}0.430^{\star \star \star} \\
(0.002)\end{array}$ \\
\hline Age3034 & $\begin{array}{l}0.692^{\star \star \star} \\
(0.004)\end{array}$ & $\begin{array}{l}0.420 * \star \star \\
(0.003)\end{array}$ & $\begin{array}{l}0.851^{\star \star \star} \\
(0.006)\end{array}$ & $\begin{array}{l}0.478^{\star \star \star} \\
(0.002)\end{array}$ \\
\hline Age3539 & $\begin{array}{l}0.723^{\star \star \star} \\
(0.004)\end{array}$ & $\begin{array}{l}0.477^{\star \star \star} \\
(0.003)\end{array}$ & $\begin{array}{l}0.931^{\star \star *} \\
(0.006\end{array}$ & $\begin{array}{l}0.529 * \star \star \\
(0.002)\end{array}$ \\
\hline Age4044 & $\begin{array}{l}0.744^{\star \star *} \\
(0.004)\end{array}$ & $\begin{array}{l}0.544^{\star \star \star} \\
(0.003)\end{array}$ & $\begin{array}{l}0.980^{\star *} \\
(0.006)\end{array}$ & $\begin{array}{l}0.578^{\star \star \star} \\
(0.002)\end{array}$ \\
\hline Age4549 & $\begin{array}{l}0.788^{* * *} \\
(0.005)\end{array}$ & $\begin{array}{l}0.639 * * * \\
(0.003)\end{array}$ & $\begin{array}{l}0.994 \\
(0.006)\end{array}$ & $\begin{array}{l}0.649 * * * \\
(0.003)\end{array}$ \\
\hline Age5054 & $\begin{array}{l}0.844^{* * *} \\
(0.005)\end{array}$ & $\begin{array}{l}0.757^{* \star *} \\
(0.004)\end{array}$ & $\begin{array}{l}0.996 \\
(0.007)\end{array}$ & $\begin{array}{l}0.743^{\star * *} \\
(0.003)\end{array}$ \\
\hline woman & $\begin{array}{l}1.321^{\star \star *} \\
(0.004)\end{array}$ & $\begin{array}{l}0.977^{* * *} \\
(0.003)\end{array}$ & $\begin{array}{l}0.899 * \star * \\
(0.003)\end{array}$ & $\begin{array}{l}1.106^{\star \star *} \\
(0.002)\end{array}$ \\
\hline edu_extended primary & $\begin{array}{l}0.544^{\star \star \star} \\
(0.005)\end{array}$ & $\begin{array}{l}0.732^{\star * *} \\
(0.009)\end{array}$ & $\begin{array}{l}1.001 \\
(0.014)\end{array}$ & $\begin{array}{l}0.568^{* * *} \\
(0.004)\end{array}$ \\
\hline edu_secondary & $\begin{array}{l}0.353^{\star \star} \\
(0.003)\end{array}$ & $\begin{array}{l}0.632^{\star \star \star} \\
(0.007)\end{array}$ & $\begin{array}{l}0.899 * \star \star \\
(0.011)\end{array}$ & $\begin{array}{l}0.403^{\star \star \star} \\
(0.003)\end{array}$ \\
\hline edu_higher vocational & $\begin{array}{l}0.245^{\star \star \star} \\
(0.003)\end{array}$ & $\begin{array}{l}0.574^{\star \star \star} \\
(0.007)\end{array}$ & $\begin{array}{l}0.858^{\star \star \star *} \\
(0.012)\end{array}$ & $\begin{array}{l}0.336^{\star \star \star} \\
(0.003)\end{array}$ \\
\hline edu_academic & 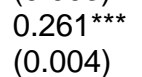 & $\begin{array}{l}0.509 * \star \star \\
(0.008)\end{array}$ & $\begin{array}{l}0.812^{\star \star \star} \\
(0.013)\end{array}$ & $\begin{array}{l}0.323^{\star \star \star} \\
(0.003)\end{array}$ \\
\hline edu_missing & $\begin{array}{l}0.565^{\star \star \star} \\
(0.004)\end{array}$ & $\begin{array}{l}0.941^{\star * *} \\
(0.009)\end{array}$ & $\begin{array}{l}0.931^{\star * *} \\
(0.010)\end{array}$ & $\begin{array}{l}0.619^{\star \star * *} \\
(0.003)\end{array}$ \\
\hline married & $\begin{array}{l}0.479 * \star \star \\
(0.002)\end{array}$ & $\begin{array}{l}0.793^{\star \star \star} \\
(0.003)\end{array}$ & $\begin{array}{l}1.026^{\star \star \star} \\
(0.005)\end{array}$ & $\begin{array}{l}0.640 \star \star \star \\
(0.002)\end{array}$ \\
\hline widowed & $\begin{array}{l}0.642^{\star \star \star} \\
(0.008)\end{array}$ & $\begin{array}{l}0.761^{\star \star \star} \\
(0.008)\end{array}$ & $\begin{array}{l}0.863^{\star \star \star} \\
(0.015)\end{array}$ & $\begin{array}{l}0.667^{\star \star \star} \\
(0.006)\end{array}$ \\
\hline separated & $\begin{array}{l}1.315^{\star \star \star} \\
(0.006)\end{array}$ & $\begin{array}{l}0.948^{\star \star \star} \\
(0.005)\end{array}$ & $\begin{array}{l}1.159 * \star \star \\
(0.007)\end{array}$ & $\begin{array}{l}1.205^{\star \star \star} \\
(0.004)\end{array}$ \\
\hline partner & $\begin{array}{l}0.389 * \star \star \\
(0.018)\end{array}$ & $\begin{array}{l}0.883^{\star \star \star} \\
(0.021)\end{array}$ & $\begin{array}{l}0.984 \\
(0.030)\end{array}$ & $\begin{array}{l}0.660^{\star \star \star} \\
(0.014)\end{array}$ \\
\hline _cons & $\begin{array}{l}5.638^{\star \star \star *} \\
(0.082)\end{array}$ & $\begin{array}{l}0.330^{\star \star \star *} \\
(0.006)\end{array}$ & $\begin{array}{l}0.127^{\star \star *} \\
(0.003)\end{array}$ & $\begin{array}{l}9.587^{\star \star \star} \\
(0.123)^{\star \star \star}\end{array}$ \\
\hline
\end{tabular}




\begin{tabular}{lllll}
\hline$R$-squared & 2149137 & 2149137 & 2149137 & 2149137 \\
\hline
\end{tabular}

\section{Origin of the Dependency on Disability Benefits}

Since disability benefits are closely related to former job of employees, we look at the distribution of people with a disability benefit over sectors where they were last employed. Tables 4a and 4b show the percentage of male and female migrant groups employed in eight distinguished sectors. Immigrants of the first generation have been mainly engaged in occupations requiring physical effort before they became disabled. Striking is the concentration of Turkish male and female immigrants in industry and detachment work which is associated with little job security. Surinamese and Antillean immigrants were more likely employed in public sector. This is possibly an outcome of colonial relations with the origin countries and their better proficiency of Dutch language. It is remarkable that about 65 to 75 percent of second generation men have a disability benefit on the basis of the young handicap regulation. This percentage is about 47 for second generation women. These young people are hardly engaged in the labour market due to structural health problems since an early stage of their life.

Table 4a Distribution of disability benefits over sectors of previous employment, MEN (\%)

\begin{tabular}{lrrrrrrr}
\hline & Agriculture & \multicolumn{1}{c}{ Industry } & Cleaning & Health & Detach & Public YoungHand Other \\
\hline Moroccan- 1st gen & 8.17 & 14.48 & 8.29 & 3.05 & 9.12 & 5.81 & 6.0845 .01 \\
Moroccan- 2nd gen & 0.13 & 2.15 & 0.54 & 1.07 & 7.11 & 2.01 & 74.7712 .21 \\
Turkish- 1st gen & 4.20 & 24.94 & 2.82 & 1.17 & 11.98 & 4.23 & 4.4346 .23 \\
Turkish- 2nd gen & 0.44 & 4.53 & 0.53 & 0.62 & 7.81 & 2.22 & 65.1318 .72 \\
Surinamese- 1st gen & 0.41 & 12.04 & 1.68 & 4.38 & 8.86 & 10.98 & 14.2947 .37 \\
Surinamese- 2nd gen & 0.24 & 2.18 & 0.65 & 1.86 & 7.03 & 1.94 & 65.9420 .18 \\
Antillean- 1st gen & 0.17 & 9.96 & 0.97 & 3.95 & 14.37 & 7.96 & 23.5839 .04 \\
Antillean- 2nd gen & 0.86 & 1.72 & 0.00 & 2.30 & 4.60 & 1.72 & 64.6624 .14 \\
Other non-west- 1st gen & 1.82 & 10.59 & 4.40 & 3.95 & 11.73 & 4.95 & 9.8352 .37 \\
Other non-west- 2nd gen & 0.43 & 2.45 & 0.29 & 1.59 & 3.46 & 2.88 & 65.4223 .49 \\
Western- 1st gen & 0.78 & 13.84 & 1.32 & 3.47 & 8.75 & 4.97 & 7.9658 .92 \\
Western- 2nd gen & 1.13 & 7.47 & 0.66 & 3.71 & 4.41 & 5.40 & 19.8457 .39 \\
& & & & & & & \\
Dutch & 8.17 & 14.48 & 8.29 & 3.05 & 9.12 & 5.81 & 6.0845 .01 \\
\hline
\end{tabular}

Table 4b Distribution of disability benefits over sectors of previous employment, WOMEN

\begin{tabular}{lrrrrrrr}
\hline & \multicolumn{1}{c}{ Agriculture Industry } & Cleaning & Health & \multicolumn{5}{c}{ Detach Public YoungHand Other } \\
\hline Moroccan- 1st gen & 1.57 & 5.61 & 18.40 & 16.22 & 9.08 & 5.09 & 8.9735 .08 \\
Moroccan- 2nd gen & 0.37 & 0.99 & 1.72 & 8.62 & 7.39 & 3.45 & 47.1730 .30 \\
Turkish- 1st gen & 6.13 & 12.22 & 11.52 & 6.15 & 22.65 & 3.79 & 3.3534 .19 \\
Turkish- 2nd gen & 2.19 & 3.06 & 1.53 & 5.76 & 13.92 & 4.30 & 37.6831 .56 \\
Surinamese- 1st gen & 0.25 & 2.81 & 5.84 & 26.94 & 8.41 & 10.41 & 7.4737 .87 \\
Surinamese- 2nd gen & 0.00 & 0.64 & 1.00 & 11.07 & 7.29 & 3.64 & 47.2129 .14 \\
Antillean- 1st gen & 0.50 & 2.80 & 3.70 & 28.14 & 9.08 & 8.30 & 15.3632 .12 \\
Antillean- 2nd gen & 0.24 & 0.98 & 0.49 & 15.16 & 5.38 & 3.42 & 40.8333 .50 \\
Other non-west- 1st gen & 1.10 & 4.63 & 12.73 & 16.36 & 11.17 & 4.43 & 11.8137 .78 \\
Other non-west- 2nd gen & 0.00 & 1.71 & 0.85 & 10.97 & 4.99 & 3.28 & 46.8731 .34 \\
Western- 1st gen & 0.87 & 6.02 & 6.44 & 18.17 & 8.77 & 5.08 & 6.0648 .59 \\
\hline
\end{tabular}




\begin{tabular}{llllllll}
\hline Western- 2nd gen & 0.75 & 2.84 & 3.71 & 20.28 & 5.45 & 4.80 & 16.8245 .35 \\
Dutch & 1.57 & 5.61 & 18.40 & 16.22 & 9.08 & 5.09 & 8.9735 .08 \\
\hline
\end{tabular}

Having risky and heavy jobs can raise the probability of becoming sick. Tables $5 \mathrm{a}$ and $5 \mathrm{~b}$ display the percentage of men and women entered disability program by main diseases. The most striking result is that neuro-psychiatric diseases are a major reason for immigrants to enter disability programs, particularly for second generation immigrants. About 40 to 49 percent of first generation male immigrants and about 42 to 56 percent of first generation female immigrants are entitled to disability benefit as a result of neuro-psychiatric diseases. This percentage is well above 70 percent for all second generation immigrants from nonwestern countries. For western migrants, the percentage of first and second generation with a neuro-psychiatric disease is quite similar to the percentages of the Dutch.

Problems with the locomotor system are the second in importance rank order.

Especially, about 25 to 32 percent of native Dutch and first generation immigrants left work force owing to a problem with the locomotor system. This percentage is significantly lower for second generation from the non-western countries, possibly caused by their younger age. Other sorts of diseases account for a smaller part of disabled work force.

Table 5a. Distribution of disability benefits over main disease symptoms, MEN

\begin{tabular}{lrrrrrr}
\hline & General Cardiovascular & Locomotor & Neuropsychiatry Respiratory Other \\
\hline Moroccan- 1st gen & 11.70 & 2.06 & 28.79 & 45.53 & 6.36 & 5.57 \\
Moroccan- 2nd gen & 7.88 & 0.54 & 5.84 & 79.21 & 1.63 & 4.89 \\
Turkish- 1st gen & 10.19 & 4.56 & 32.73 & 40.57 & 6.61 & 5.35 \\
Turkish- 2nd gen & 7.42 & 0.72 & 9.75 & 75.94 & 1.07 & 5.10 \\
Surinamese- 1st gen & 13.67 & 8.23 & 22.67 & 44.79 & 4.63 & 6.01 \\
Surinamese- 2nd gen & 8.99 & 2.29 & 7.52 & 74.10 & 1.31 & 5.80 \\
Antillean- 1st gen & 14.26 & 5.48 & 22.75 & 48.56 & 3.41 & 6.54 \\
Antillean- 2nd gen & 10.14 & 1.45 & 9.57 & 71.88 & 1.45 & 5.51 \\
Other non-west- 1st gen & 9.77 & 5.77 & 32.54 & 40.22 & 5.64 & 6.05 \\
Other non-west- 2nd gen & 9.26 & 1.45 & 9.55 & 73.37 & 2.03 & 4.34 \\
Western- 1st gen & 12.99 & 8.30 & 31.34 & 37.22 & 5.25 & 4.90 \\
Western- 2nd gen & 14.45 & 6.57 & 25.54 & 45.17 & 3.88 & 4.38 \\
& & & & & & \\
Dutch & 13.65 & 6.58 & 29.88 & 41.38 & 3.70 & 4.81 \\
\hline
\end{tabular}

Table 5b Distribution of disability benefits over main disease symptoms, WOMEN

\begin{tabular}{lrrrrrr}
\hline & General & Cardiovascular & Locomotor & Neuropsychiatry Respiratory Other \\
\hline Moroccan- 1st gen & 8.80 & 1.31 & 22.16 & 56.36 & 4.00 & 7.37 \\
Moroccan- 2nd gen & 8.27 & 0.64 & 8.65 & 74.05 & 1.91 & 6.49 \\
Turkish- 1st gen & 8.47 & 2.05 & 23.93 & 55.31 & 4.09 & 6.15 \\
Turkish- 2nd gen & 7.78 & 0.45 & 9.42 & 72.85 & 2.09 & 7.40 \\
Surinamese- 1st gen & 14.90 & 3.37 & 22.54 & 47.51 & 3.31 & 8.38 \\
Surinamese- 2nd gen & 10.73 & 1.24 & 10.15 & 67.59 & 1.90 & 8.39 \\
Antillean- 1st gen & 15.93 & 4.05 & 23.53 & 44.09 & 2.51 & 9.88 \\
Antillean- 2nd gen & 9.41 & 1.49 & 14.85 & 66.58 & 2.23 & 5.45 \\
Other non-west- 1st gen & 10.55 & 3.64 & 28.62 & 43.78 & 3.71 & 9.70 \\
Other non-west- 2nd gen & 15.09 & 1.16 & 9.78 & 65.60 & 2.90 & 5.37 \\
Western- 1st gen & 12.33 & 3.12 & 27.49 & 46.15 & 3.73 & 7.17 \\
Western- 2nd gen & 13.95 & 2.54 & 22.63 & 50.34 & 3.62 & 6.92 \\
& & & & & & \\
\hline
\end{tabular}




\begin{tabular}{lllllll}
\hline Dutch & 13.6 & 2.78 & 2532 & 47.74 & 3.54 & 7.01 \\
\hline
\end{tabular}

\section{Exit Out of Disability benefit}

Our data provide information on exit out of the disability program. Exits usually take place after recovering and approval of medical doctors. It is interesting to know how exit probabilities vary across migrant groups. We estimate two probit models to assess determinants of exit: in the first model, we use all observed variables except age and in the second model we also include age in addition to other variables. The first model in Table 6 suggests that non-western immigrants have clearly greater exit rates than western immigrants of the first generation, the reference group. For second generation Moroccan and Turkish immigrants exit rates are even twice as high as the rate of the reference group. This picture changes fundamentally when we include age in the second model. The relative exit probabilities decline for non-western immigrants substantially. Younger benefits claimants, in particular those who are in their twenties and thirties have greater chances to find a job. Since second generation immigrants are often in these age categories, their higher exit probabilities do not necessarily maintain these relatively high levels after correction for age. The exit rates of Non-western immigrants are either just above or well below the exit rates of Western immigrants. The estimated lower exit rates are, however, significant only for the Moroccan and Surinam first generation and Other Non-Western second generation.

In both models more recent immigrants have better chances to exit disability benefits, but in the age corrected model this effect is smaller. This age effect is also observable in the estimates of marital status. The first model suggests that unmarried immigrants perform better in terms of exit rates than widowers, separated and married immigrants. Since unmarried immigrants are probably younger than most married, separated immigrants and widowers, the second model shows a different picture; exit rate estimates of separated and married immigrants are significantly higher than those of unmarried immigrants. While estimates of all educational levels point out higher exit rates than the lowest educational level, exit rates do not necessarily increase with the level of education monotonously.

Table 6 Estimation of exit rates

\begin{tabular}{|c|c|c|}
\hline & Model I & Model II \\
\hline Moroccan- 1st gen & $\begin{array}{l}1.276^{\star \star \star} \\
(0.029)\end{array}$ & $\begin{array}{l}0.886^{\star \star *} \\
(0.022)\end{array}$ \\
\hline Moroccan- 2nd gen & $\begin{array}{l}1.693^{\star \star \star} \\
(0.253)\end{array}$ & $\begin{array}{l}0.822 \\
(0.125)\end{array}$ \\
\hline Morocco3 & 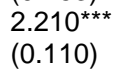 & $\begin{array}{l}1.038 \\
(0.056)\end{array}$ \\
\hline Turkish- 1st gen & $\begin{array}{l}1.472^{* * *} \\
(0.030)\end{array}$ & $\begin{array}{l}1.023 \\
(0.023)\end{array}$ \\
\hline Turkish- 2nd gen (mixed) & $2.143^{* \star *}$ & 1.076 \\
\hline Turkey- 2nd gen & $\begin{array}{l}(0.270) \\
2.443^{\star \star \star} \\
(0.095)\end{array}$ & $\begin{array}{l}(0.140) \\
1.031 \\
(0.045)\end{array}$ \\
\hline Surinamese- 1st gen & $\begin{array}{l}1.047^{* *} \\
(0.026)\end{array}$ & $\begin{array}{l}0.924^{\star *} \\
(0.024)\end{array}$ \\
\hline Surinamese- 2nd gen (mixed) & $\begin{array}{l}1.573^{* * *} \\
(0.101)\end{array}$ & $\begin{array}{l}0.937 \\
(0.063)\end{array}$ \\
\hline Surinamese- 2nd gen & $\begin{array}{l}1.847^{\star \star \star} \\
(0.097)\end{array}$ & $\begin{array}{l}0.990 \\
(0.055)\end{array}$ \\
\hline Antillean- 1st gen & $\begin{array}{l}1.066 \\
(0.043)\end{array}$ & $\begin{array}{l}1.034 \\
(0.044)\end{array}$ \\
\hline Antillean- 2nd gen (mixed) & $\begin{array}{l}2.033^{\star \star \star} \\
(0.157)\end{array}$ & $\begin{array}{l}1.091 \\
(0.087)\end{array}$ \\
\hline Antillean- 2nd gen & $1.554^{\star \star}$ & 0.839 \\
\hline
\end{tabular}




\begin{tabular}{|c|c|c|}
\hline Other non-west- 1st gen & $\begin{array}{l}(0.236) \\
1.163^{\star \star \star} \\
(0.030)\end{array}$ & $\begin{array}{l}(0.131) \\
1.032 \\
(0.028)\end{array}$ \\
\hline Other non-west- 2nd gen (mixed) & $1.480^{\star \star \star}$ & 0.917 \\
\hline Other non-west- 2nd gen & $\begin{array}{l}(0.109) \\
1.171 \\
(0.143)\end{array}$ & $\begin{array}{l}(0.070) \\
0.642^{\star \star \star} \\
(0.079)\end{array}$ \\
\hline Western- 2nd gen (mixed) & $\begin{array}{l}1.291^{\star \star \star} \\
(0.028)\end{array}$ & $\begin{array}{l}0.965 \\
(0.023)\end{array}$ \\
\hline Western- 2nd gen & $\begin{array}{l}1.436^{\star \star \star} \\
(0.047)\end{array}$ & $\begin{array}{l}1.003 \\
(0.035)\end{array}$ \\
\hline Immigrated between 2004-2005 & $\begin{array}{l}2.685^{\star \star \star} \\
(0.722)\end{array}$ & $\begin{array}{l}2.261^{\star *} \\
(0.651)\end{array}$ \\
\hline Immigrated between 2000-2003 & $\begin{array}{l}2.262^{\star \star \star} \\
(0.126)\end{array}$ & $\begin{array}{l}1.415^{\star \star \star} \\
(0.083)\end{array}$ \\
\hline Immigrated between 1995-1999 & $\begin{array}{l}2.274^{\star \star \star} \\
(0.056)\end{array}$ & $\begin{array}{l}1.417^{\star \star \star} \\
(0.038)\end{array}$ \\
\hline Immigrated between 1990-1994 & $\begin{array}{l}1.873^{\star \star \star} \\
(0.036)\end{array}$ & $\begin{array}{l}1.245^{\star \star \star} \\
(0.027)\end{array}$ \\
\hline Immigrated between 1980-1989 & $\begin{array}{l}1.501^{\star \star \star} \\
(0.026)\end{array}$ & $\begin{array}{l}1.096^{\star \star \star} \\
(0.021)\end{array}$ \\
\hline Immigrant_Dutch citizen & $\begin{array}{l}0.739 * \star \star \\
(0.039)\end{array}$ & $\begin{array}{l}0.788^{\star \star \star} \\
(0.043)\end{array}$ \\
\hline Immigrant_Dutch and Foreign citizen & $\begin{array}{l}1.105 \\
(0.083)\end{array}$ & $\begin{array}{l}1.134 \\
(0.090)\end{array}$ \\
\hline age1924 & & $\begin{array}{l}2.616^{\star \star *} \\
(0.101)\end{array}$ \\
\hline age2529 & & $\begin{array}{l}4.007^{* \star *} \\
(0.126)\end{array}$ \\
\hline age3034 & & $\begin{array}{l}4.511^{\star \star \star} \\
(0.122)\end{array}$ \\
\hline age3539 & & $\begin{array}{l}3.723^{\star \star \star} \\
(0.094)\end{array}$ \\
\hline age 4044 & & $\begin{array}{l}2.620^{* * *} \\
(0.067)\end{array}$ \\
\hline age4549 & & $\begin{array}{l}2.043^{\star * *} \\
(0.053)\end{array}$ \\
\hline age5054 & & $\begin{array}{l}1.479 \text { *** } \\
(0.042)\end{array}$ \\
\hline woman & $\begin{array}{l}1.217^{\star *} \\
(0.014)\end{array}$ & $\begin{array}{l}1.036^{\star \star} \\
(0.013)\end{array}$ \\
\hline edu_extended primary & $\begin{array}{l}1.221^{\star \star \star} \\
(0.059)\end{array}$ & $\begin{array}{l}1.166^{\star \star} \\
(0.059)\end{array}$ \\
\hline edu_secondary & $\begin{array}{l}1.354^{\star \star \star} \\
(0.056)\end{array}$ & $\begin{array}{l}1.136^{* *} \\
(0.050)\end{array}$ \\
\hline edu_higher vocational & $\begin{array}{l}1.274^{\star \star \star} \\
(0.067)\end{array}$ & $\begin{array}{l}1.076 \\
(0.060)\end{array}$ \\
\hline edu_academic & $\begin{array}{l}1.373^{\star \star \star} \\
(0.088)\end{array}$ & $\begin{array}{l}1.176^{\star} \\
(0.081)\end{array}$ \\
\hline edu_missing & $\begin{array}{l}1.062 \\
(0.036)\end{array}$ & $\begin{array}{l}1.033 \\
(0.037)\end{array}$ \\
\hline married & $\begin{array}{l}0.864^{\star \star \star} \\
(0.012)\end{array}$ & $\begin{array}{l}1.153^{\star \star \star} \\
(0.019)\end{array}$ \\
\hline widowed & $\begin{array}{l}0.540 \text { *** } \\
(0.034)\end{array}$ & $\begin{array}{l}1.028 \\
(0.070)\end{array}$ \\
\hline separated & $\begin{array}{l}0.877^{\star \star \star} \\
(0.016)\end{array}$ & $\begin{array}{l}1.203^{\star \star \star} \\
(0.024)\end{array}$ \\
\hline partner & $\begin{array}{l}0.832 \\
(0.093)\end{array}$ & $\begin{array}{l}0.999 \\
(0.119)\end{array}$ \\
\hline _cons & $\begin{array}{l}0.146^{\star \star \star} \\
(0.010)\end{array}$ & $\begin{array}{l}0.082^{\star \star \star} \\
(0.006)\end{array}$ \\
\hline $\begin{array}{l}\text { R-squared } \\
\mathrm{N}\end{array}$ & 163289 & 163289 \\
\hline
\end{tabular}

\section{Where do new immigrants work?}

The perceived concentration of immigrants in welfare programmes may be related to the quality of jobs. Previous studies suggest that foreign education and experience have little value for new immigrants in the beginning. Therefore, immigrants usually start with a low qualified job in the host country labour markets. With duration of residence they are expected 
to improve their position. However, this initial poor starting position can generate skill depreciation if immigrants should keep low skilled jobs. In this section we look at sectors where immigrants start to work and later move to. Tables $7 \mathrm{a}$ and $7 \mathrm{~b}$ show the distribution of immigrants arrived in different periods over sectors. A compelling result is that immigrants seem to start with jobs in cleaning and detachment sectors. Jobs in these sectors are generally associated with a low security and low wages. There is hardly any educational requirement for these jobs. As duration of residence increases, the share of immigrants in these sectors clearly decreases. An increasing share of earlier immigrants is employed in public and health sectors. At the same time, more immigrants attend subsidised employment programmes.

Table 7a. Sector of employment by year of immigration, males (\%)

\begin{tabular}{lrrrrrrrrrrr}
\hline & \multicolumn{3}{c}{ Industry } & Cleaning Cater & \multicolumn{3}{c}{ Health Financial Detach Subsid. Public Other } & Unknown \\
\hline Immigrated between 2004-2005 & 7.30 & 16.92 & 10.18 & 0.67 & 3.86 & 34.24 & 0.00 & 0.77 & 11.31 & 14.76 \\
Immigrated between 2000-2003 & 12.94 & 15.40 & 11.57 & 1.87 & 3.00 & 22.75 & 0.96 & 0.99 & 15.71 & 14.80 \\
Immigrated between 1995-1999 & 23.18 & 8.16 & 10.45 & 2.76 & 3.85 & 14.34 & 1.21 & 2.80 & 19.35 & 13.90 \\
Immigrated between 1990-1994 & 24.71 & 7.16 & 9.08 & 4.22 & 4.31 & 11.28 & 1.98 & 5.69 & 17.73 & 13.86 \\
Immigrated between 1980-1989 & 27.34 & 4.87 & 7.60 & 4.58 & 5.79 & 9.33 & 3.21 & 8.48 & 17.74 & 11.05 \\
Immigrated between 1970-1979 & 32.13 & 3.39 & 4.74 & 4.59 & 6.14 & 5.63 & 4.57 & 11.62 & 17.96 & 9.24 \\
\hline Immigrated before 1970 & 34.69 & 3.28 & 3.05 & 5.99 & 3.50 & 3.84 & 7.80 & 11.64 & 16.72 & 9.49 \\
\hline
\end{tabular}

Table $7 \mathrm{~b}$. Sector of employment by year of immigration, females (\%)

\begin{tabular}{lrrrrrrrrrr}
\hline & \multicolumn{3}{c}{ Industry Cleaning Catering Health Financial Detach Subsid. Public Other } & Unknown \\
\hline Immigrated between 2004-2005 & 4.51 & 35.86 & 6.35 & 2.46 & 4.71 & 21.31 & 0.00 & 1.02 & 9.22 & 14.55 \\
Immigrated between 2000-2003 & 3.45 & 35.83 & 8.05 & 6.91 & 8.36 & 17.95 & 1.30 & 1.63 & 5.89 & 15.63 \\
Immigrated between 1995-1999 & 5.55 & 26.88 & 11.00 & 13.46 & 3.87 & 11.02 & 1.90 & 3.05 & 8.98 & 14.31 \\
Immigrated between 1990-1994 & 5.61 & 23.97 & 11.42 & 18.74 & 5.11 & 8.18 & 1.99 & 5.52 & 8.25 & 11.23 \\
Immigrated between 1980-1989 & 5.33 & 19.83 & 8.83 & 19.76 & 8.56 & 7.59 & 2.43 & 9.69 & 8.83 & 9.16 \\
Immigrated between 1970-1979 & 6.42 & 13.66 & 4.64 & 23.88 & 9.42 & 4.45 & 3.55 & 16.55 & 8.59 & 8.84 \\
\hline Immigrated before 1970 & 5.73 & 5.29 & 4.85 & 23.79 & 7.93 & 3.08 & 2.64 & 25.11 & 10.13 & 11.45 \\
\hline
\end{tabular}

\section{Conclusion and discussion}

The welfare state provides social welfare programs to ensure a minimum living standard for all its residents. The formal entitlement conditions are to apply to all legal inhabitants of the Netherlands irrespective immigrant status. Immigrants and their children have, in principle, full access to these programs. This paper examined the degree of participation in social assistance and disability and unemployment benefits across migrant groups using administrative data covering entire migrant population aged 19 to 64 years. The emphasis was on interethnic differences in social welfare use.

The analysis shows that migrants from non-western countries, both first and second generation, have a higher probability to participate in social assistance and disability benefit programs and to less extent in unemployment benefit programs. The substantially high observed concentration of non-western immigrants in social assistance is remarkable. However, when we control for background variables, the overrepresentation of non-western immigrants in social assistance declines from about five times of that of western immigrants to twice of this. Strikingly, the degree of dependence of second generation non-western on social assistance is quite similar to their parents when we account for age differences. This 
outcome is not expected since second generation have a clearly more advantaged position regarding their relative higher education level and better language proficiency.

First generation immigrants from Turkey, Morocco and Suriname have a higher probability of disability benefit use. There is some evidence that this has been caused by the nature of their employment history. They were often employed in heavy and risky jobs. The probability of disability benefit is slightly higher for second generation non-western immigrants. An overwhelmingly large share of this second generation entered disability program as a result of neuropsychiatric symptoms.

More recent policy changes which imposed more restrictions on immigration flows and on welfare use of immigrants, have slightly reduced benefit use of recent immigration cohorts. More restrictive immigration and integration policies seem to be important in order to activate new immigrants. However, it is now too early to measure the impact of new policies. There is some evidence that this decline could be a temporary phenomenon. New immigrants tend to enter welfare programmes with some delay. Welfare dependency is typically relatively higher for immigrants who arrived in the 1990s, when the Netherlands was searching effective immigration and integration policies. Perhaps therefore, policies to improve active participation of immigrants are moving to a direction that immigrants should stepwise obtain entitlement to a benefit in the host country, rather that taking entitlement as granted at entry. A more complex problem is, however, the relatively high welfare dependency of second generation for which no feasible effective policy tool is available. Schooling is perhaps most efficient tool to improve the position of second generation.

The perceived relative high welfare use of immigrants is one of central issues. It is often mentioned that the generous welfare system attracts immigrants with a high probability of welfare use. However, Dutch immigration policies are often not selective regarding skills levels of newly entering immigrants. Most immigrants from developing countries are allowed to enter the Netherlands on the basis of humanitarian reasons, as family or asylum migrants. So, a higher welfare dependency of immigrants is inherent to the admittance policy. Recently immigration policies have changed to restrict family and asylum migration. Newly arriving immigrants should now learn Dutch language and relevant institutions during a citizenship course upon arrival. Their participation in welfare system is conditional on the certificate of citizenship course. Obligatory language training and some training to obtain knowledge about relevant Dutch institutions, called citizenship course, have a potential to prevent immigrant welfare dependency, in particular in the long run. At the same time, this policy change can discourage potential immigrants with low incentives for active participation.

Evidence suggests that the proficiency of local language is crucial for immigrants. Immigrants without sufficient language proficiency are highly vulnerable to business cycles and other fluctuations. A steady adjustment of immigrants with a relatively low skill level in the host country labour markets critically depends on the proficiency of local language and other host country specific capital. Obtaining of this asset does not have linear pattern. It is rather concentrated within the very first years after immigration. The efficiency of obtaining this asset strongly decreases with the duration of residence. Therefore, policies designed to provide immigrants upon arrival with home country specific capital are expected to work better. In that sense, the new policy of the obligatory initial training is expected to pay off soon although the implementation of this policy needs to be improved drastically. It is difficult to find incentives for older immigrants with certain history in the Netherlands. However, the expected low efficiency of policies to activate earlier immigrants may not be a reason for any laissez faire policy for these immigrants. There is still enough benefit to receive from the active labour market participation of earlier immigrants. Any improvement 
in their position will likely return to their children, which is an important avenue of intergenerational upward mobility.

There are indications that the current economic crisis has hit non-western immigrants relatively harder than native Dutch and other relatively less vulnerable western immigrants, like other earlier crises. Immigrants have lost their jobs quicker because they have often temporary contracts with low job security. While immigrants are more likely to enter welfare programs, there is increasingly little money for active labour market policies aiming to help immigrants in finding a job because of necessary cutbacks to repair budget deficits. This is a typical situation in which disadvantages of immigrants become greater and more persistent.

\section{References}

CBS (2008). Jaarrapport integratie 2008. Den Haag

Ferber, T. (2008). Personen met een uitkering. Sociaaleconomische trends, 2008/1, $25-34$.

Hartog, J. and A. Zorlu (2009). How Important is Homeland Education for Refugees'

Economic Position in the Netherlands?, Journal of Population Economics, 22, 219246

IWI/IND (2008), Bijstand, WW en verblijfvergunning: Onderzoek van het Informatie en Analyse Centrum van de IND en de Inspectie Werk en Inkomen naar de samenwerking tussen gemeenten en IND en naar de toetsing op rechtmatig verblijf door CWI/UWV.

Klaver, J., A. Odé en M. van Gent (2007). Vluchtelingenwerk integratiebarometer 2006. Amsterdam: Regioplan Beleidsonderzoek.

Kroeze, H. (2008). De uitstroomparadox. Sociaaleconomische trends, 2008/2, 32-36.

SCP/WODC/CBS (2005). Jaarrapport integratie 2005. Den Haag

SCP (2007). Jaarrapport integratie 2007. Den Haag

SCP/WODC/CBS (2009). Jaarrapport integratie 2009. Den Haag

Snel, E. (2002). In de fuik. Turken en Marokkanen in de WAO. Utrecht: Verwey-Jonker Instituut.

SEO (2009). De economische impact van arbeidsmigratie uit de MOE-landen, Bulgarije en Roemenie; een studie naar omvang, aard en economische effecten van arbeidsmigratie, Amsterdam: SEO

Vliet, H.N. van der, M.C.C. Wageveld en M.J. Garssen (2007). Trends in de positie van nietwesterse allochtonen. In: R.P.W. Jennissen en J. Oudhof (red.), Ontwikkelingen in de maatschappelijke participatie van allochtonen. Een theoretische verdieping en een thematische verbreding van de Integratiekaart 2006 (pp. 23-56). Meppel: CBS/WODC/Boom Juridische uitgevers.

Versantvoort, M et al. (2006). Evaluatie Werknemers-verkeer MOE-landen. Rotterdam: Ecorys. 